\title{
Shalapko D. \\ AN EXPERIMENTAL STUDY OF THE WAVE EFFECT IN FUEL EOUIPMENT USING HYDROGEN ADDITIVES TO DIESEL FUEL
}

Об'єктом дослідження є гідродинамічні хвильові ефекти в паливній апаратурі високого тиску дизельних двигунів. Одним з найбільш проблемних явищ, при використанні добавок водню у дизельному паливі є зміна максимального тиску впорскування палива, що призводить до погіршення параметрів розпилу палива.

Для проведення досліджень характеру гідравлічних коливань в паливній апаратурі створено експериментальний стенд, який дозволяє проводити дослідження хвильового ефекту при використанні малих добавок водню до основного паливу. При розробці експериментального стенду застосовувалися сучасні високоточні вимірювальні прилади. За результатами проведення експериментальних досліджень було встановлено, що в паливній магістралі високого тиску виникає характерний «хвильовий ефект» коливань. Даний ефект викликаний посадкою нагнітального клапану на сідло в паливному насосі високого тиску, а також посадкою голки форсунки. Характер коливань залежить від таких факторів, як довжина трубопроводу між насосом і форсункою, максимальний тиск уприскування дизельного палива, швидкість розповсюджень хвилі тиску. Дана швидкість, в свою чергу, залежить від частоти обертання колінчатого валу двигуна. Частота обертання валу паливного насоса змінювалась за допомогою всережимного регулятора $і$ частотоміра приводного електродвигуна.

В результаті отримані характеристики впорскування палива, які відображають характер зміни хвилі тиску в залежності від наявності водневої добавки. Визначено, що добавка водню в розмірі 0,1\% від циклової подачі палива (по масі) призводить до пригнічення хвильових коливань і укорочення ділянки коливань на 12..20\%. Отримані характеристики абсорбиї водню дизельним паливом. Витрата водневої добавки залежить від частоти обертання валу насоса, тиску уприскування і тиску подачі добавки. Такий характер витрати водню пояснюється часовими рамками обмеження процесу абсорбцї, різницею мінімального значення «хвилі тиску» надлишкового тиску добавки. Отримані в результаті дані можна використовувати для підтвердження математичної моделі абсорбцї водню при використанні його в якості добавки в паливопровід.

Ключові слова: двигун внутрішнього згоряння, витрата водню, водневі добавки.

\section{Introduction}

The limited reserves of fossil organic energy necessitate a wider use of alternative fuels and fuel additives in transport units. For the coming decades, for small and medium transport and stationary power plants, one of the main types of engines will remain turbo piston internal combustion engines (ICE) with compression ignition. The task of increasing the efficiency of such engines can be solved, in particular, through the use of promising fuel additives [1, 2].

As additives to diesel fuel can be used [3]:

- gas engine fuel (liquefied or compressed natural gas);

- liquefied petroleum gases (propane, butane);

- alcohols and benzyl alcohol mixtures (methyl, ethyl, isobutyl and other alcohols and their mixtures with gasoline in various proportions);

- ethers (methyl tertiary butyl ether, methyl tert-methyl ether, ethyl tertiary butyl ether, diisopropyl ether, and also dimethyl ether);

- synthetic liquid fuels derived from natural gas and coal; - biofuels (bioethanol, biodiesel) derived from renewable raw materials;

- hydrogen and hydrogen based fuel additives.
The paper presents an experimental study of the effect of the use of hydrogen gas additives in the line of high fuel equipment of the internal combustion engine on the characteristics of the «wave effect» and the characteristics of injection of the internal combustion engine.

Therefore, it is relevant to study the possibility of using hydrogen additives in the high-pressure fuel line through a special non-return valve due to the «wave effect» in the fuel equipment $[4,5]$.

\section{The object of research and its technological audit}

The object of research is hydrodynamic wave effects in the high-pressure fuel equipment of diesel engines. Due to the use of the «wave effect» with the help of a special non-return valve it is possible to carry out small additives ( $0.1 \ldots 0.5 \%$ by mass) of hydrogen to the main fuel. The constructive scheme of the non-return valve is shown in Fig. 1.

Among the proposed options for additives to the main fuel, hydrogen is of particular interest, since, according to [6, 7], even minimal additions of hydrogen $(0.1-0.5 \%$ by mass) have a positive effect on the environmental and economic performance of a diesel engine. 


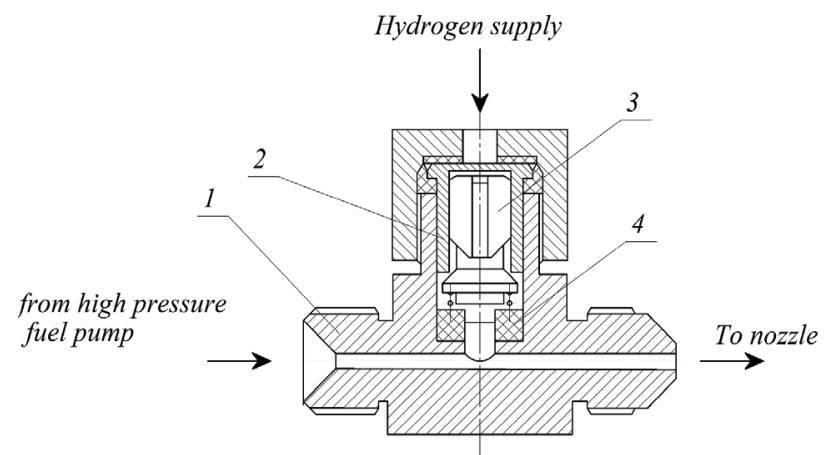

Fig. 1. Device for supplying hydrogen to the high pressure line: 1 - tee body; 2 - valve body; 3 - non-return valve with a guide shaft; 4 - valve stroke stop

Structurally rational is the supply of hydrogen to the high-pressure fuel line between the high-pressure fuel pump (HPFP) and the nozzle. The peculiarity is adding hydrogen to diesel fuel to the high-pressure line on a low-pressure wave using a special device. In this case, in the pressure wave, diesel fuel is saturated with hydrogen and enters the nozzle and then injected into the engine cylinder. After injection and reduction of pressure in the cylinder, hydrogen is released from diesel fuel, contributes to the further grinding of the droplets and quickly diffuses into the volume of the over-piston space. The amount of hydrogen that is added to the cycle supply of diesel fuel is regulated by the hydrogen supply pressure at the inlet to the mixing device (Fig. 1) [2]. However, when using gas additives, one should not exceed the limits of gas solubility in the fuel in order to avoid the occurrence of gas locks in the high-pressure fuel line.

This method is very simple to use and does not require a significant change in engine design. However, in the special scientific and technical literature, the proposed method of adding hydrogen has been little studied, which predetermines the promise of its experimental research.

\section{The aim and objectives of research}

The aim of research is obtaining the dependences of the diesel fuel saturation with a hydrogen additive for the formation of a mathematical model. To achieve this aim it is necessary to perform the following objectives:

1. To develop a physical model of wave oscillations in the fuel equipment of a diesel engine.

2. To create an experimental stand for studying the wave effect with small additions of hydrogen to the highpressure fuel line.

3. To obtain qualitative results on its effect on the engine parameters.

\section{Research of existing solutions of the problem}

The method of adding hydrogen, which is described in [7], shows a high ecological efficiency in the use of small additions of hydrogen with the help of a dual-fuel injector. However, in this work the «wave effect» of fuel equipment and the effect of hydrogen on the hydraulic characteristics in the fuel line are not fully revealed.

Among the main ways to increase the efficiency of the internal combustion engine through the use of hydrogen as an additive to the main fuel identified in the resources of world periodicals, can be highlighted [8, 9]. But they consider only the supply of hydrogen in the intake manifold. The works $[3,10]$ are devoted to the consideration of the influence of the addition of hydrogen on the environmental parameters of a diesel engine, with an analysis of the rational ratio of hydrogen to fuel. But the question remains of the cost ratio of hydrogen when it is added to $20 \%$.

An alternative solution to the problem, outlined in [11], does not provide for the addition of hydrogen to the fuel, but uses direct hydrogen supply to the diesel cylinder. At the same time, works $[11,12]$ use from 8 to $45 \%$ of hydrogen with respect to diesel fuel. The use of hydrogen as an additive to the main fuel plays a role only in increasing the energy intensity of the fuel according to the authors of [13]. This is not confirmed either experimentally or by modeling. The addition of hydrogen in the amount of $3 \%$ by mass leads to an increase in the efficiency of the power plant with ICE by $1.5 \%$, as shown in [14]. However, in this case, hydrogen acts as both a combustion catalyst and a fuel, since with this addition the energy potential reaches $10 \%$ of the main fuel. The use of hydrogen in HCCI in the amount of an additive up to $17 \%$ shows that a smaller proportion of the additive is more effective and leads to a «softer» engine operation [15]. Although this statement concerns only this type of engine and is not widely used in the global engine-building industry.

\section{Methods of research}

The physical model of the spray and the possibility of using hydrogen additives on the discharge line require further theoretical and experimental research to determine the rational parameters of the additive supply and control of the fuel injection process. One of the research methods is physical modeling, which allows to obtain fairly accurate results.

In modern high-speed diesel engines, the fuel supply process takes only $1 \ldots 4 \mathrm{~ms}$ at a high speed of the pump plunger [4]. Compression and fuel injection have a pulsed non-stationary character. The fuel itself is an elastic medium in which the pressure propagates at a speed of sound (1200-1600 m/s), and any, even slight, change in volume in a filled hydraulic system causes an abrupt pressure change.

The pressure pulses propagating from the disturbance source, encountering obstacles at the ends of the system, are partially reflected and form reverse and total waves, strongly distorting the injection characteristics. At the end of the fuel supply, pressure waves, reflected from a closed discharge valve, can cause repeated needle jumps after the main injection period is completed. The resulting socalled sub-injections are undesirable because the injection pressure is small and the atomization of the fuel is coarse and heterogeneous. Sub-injection flow leads to an increase in the smoke of exhaust gases, an increase in carbon formation, an increase in the specific fuel consumption and creates prerequisites for coking of the atomizer openings.

After the end of the fuel supply, the movement and reflection of waves in the high-pressure cavity (pump nozzle discharge pipe - nozzle) gradually subside due to irreversible energy loss due to friction, and residual pressure is established in it. Usually, the longer the fuel line and the higher the frequency of the injection pulses, the stronger the influence of wave phenomena in the system on the fuel 
delivery characteristics. This factor does not have such an effect on the «pump-injector» section, where there is no injection pipe and the wave effect is negligible.

\section{Research results}

In order to study these processes in detail, an experimental unit ДВС-1-МДВ is developed on the basis of the fuel system of the D65 (4Ч11/13) diesel engine (USSR). The experimental unit is shown in Fig. 2, its appearance is shown in Fig. 3, 4.

The experimental unit consists of three subsystems:

- subsystem for physical modeling of fuel injection processes with the addition of hydrogen gas (based on the fuel system of the D65 engine);

- subsystem of removal and automated processing of measurement data;

- subsystem of automatic control of unit parameters.

From a cylinder 1 with a volume of 5 liters (Fig. 2), hydrogen through a reducer 2 enters the additive addition valve 4, which is installed in front of the fitting of a standard nozzle 12 mounted on a rod and installed with a spray element in a measuring cup 11.

The pressure value in the fuel line is converted into a current signal by a dynamic fiber optic pressure sensor 13 for high-temperature pressure measurements «Optrand AutoPSI-S2000» (USA) with an upper limit of $200 \mathrm{MPa}$ and an output signal of $0.5 \ldots 5.0 \mathrm{~V}$. It allows to determine the moment of the start of fuel injection, qualitatively estimate the magnitude of the pressure of the fuel and explore the processes in the high-pressure pipeline.

The signals from the primary sensors from the ДВС1-МДВ stand are electronically transmitted to the USB oscilloscope and to the computerized measurement and data recording system «IRIS» (Russia) 10.

Modern primary transducers of measured physical quantities into electrical signals together with computerized hardware for conducting experimental research and software for processing experimental data based on CAD systems ensure sufficient reliability of the obtained experimental information.

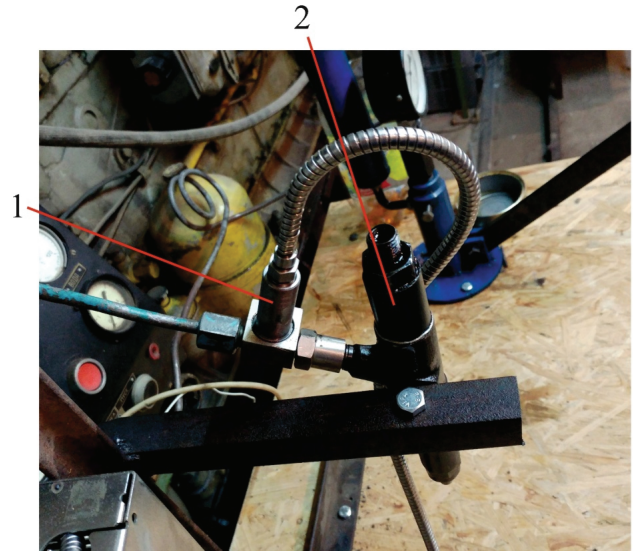

Fig. 3. Installation of the Optrand AutoPSI-52000 sensor (USA) in the high pressure line: 1 - pressure sensor; 2 - nozzle

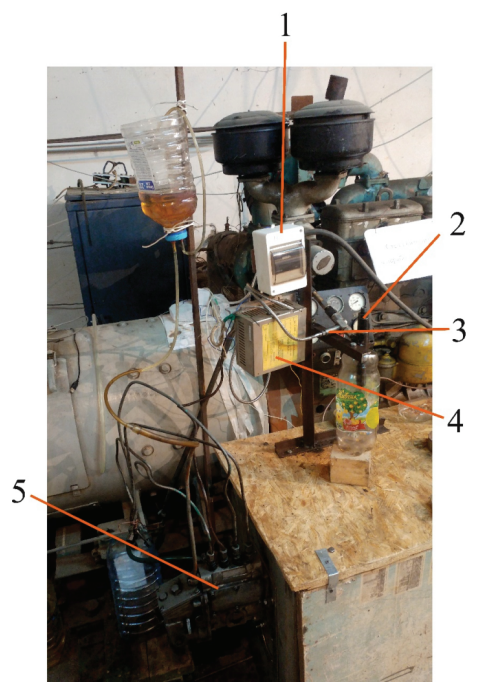

Fig. 4. Experimental unit on the basis of the fuel equipment of the 4Ч11/13 engine: 1 - power supply unit for «OBEH»; pressure sensors; 2 - nozzle; 3 - pressure sensor; 4 - signal filter block; 5 - high pressure fuel pump

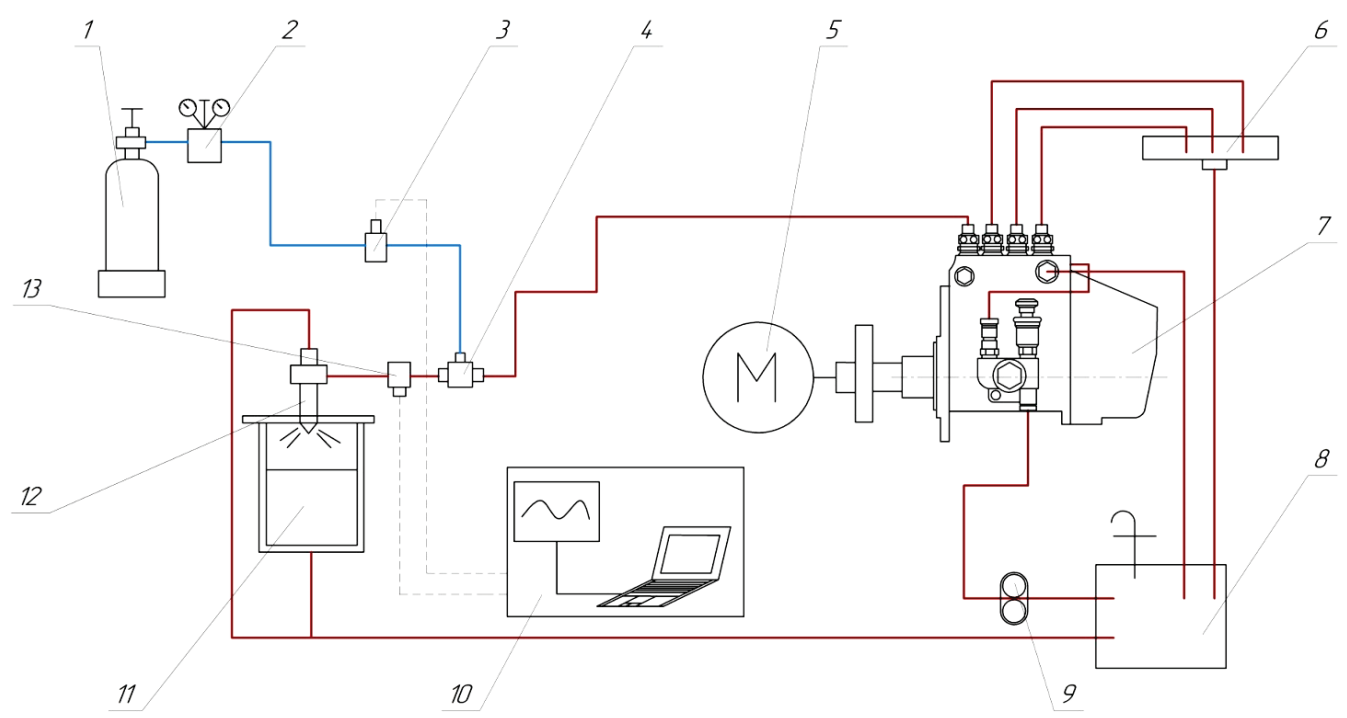

Fig. 2. Scheme of ДВС-1-МДВ experimental unit:

1 - cylinder with compressed hydrogen; 2 - industrial hydrogen reducer; 3 - pressure sensor; 4 - valve for adding hydrogen to the high pressure fuel line; 5 - electric motor; 6 - fuel discharge tank; 7 - high pressure fuel pump; 8 - supply tank; 9 - fuel boost pump; 10 - computer system for collecting and processing measurement data; 11 - injection tank; 12 - nozzle; 13 - pressure sensor 
Characteristics of the main measuring equipment of the experimental stand DVS-1-MDV are given in Table 1.

Fig. 5 shows the fuel injection diagrams with the addition of hydrogen (Fig. 5, $a$ ) and without the additive (Fig. 5, b), obtained experimentally.

An analysis of these data shows that with the addition of hydrogen gas to the fuel, the effect of wave oscillations in the high-pressure line is «smoothed out», however, a noticeable significant decrease in the maximum fuel injection pressure (Fig. 6) after the start of the additive supply is noticeable.

The presence of an additive of hydrogen in the amount of $v=0.1 \%$, with the serial tightening of the needle spring of the injector $P_{n s}=17.6 \mathrm{MPa}$, as can be seen from Fig. 6, causes a decrease in the maximum injection pressure $P_{\text {in }}$ by $2 \ldots 3 \mathrm{MPa}$.

Reducing the maximum injection pressure can be explained by changing the physicochemical properties of the fuel.
As a result of processing the obtained experimental data, the dependences of the supply of a small addition of hydrogen (by mass) on the feed pressure and on the crankshaft rotation frequency (Fig. 7) are established. At the same time, the hydrogen pressure varied within $2 \ldots 10 \mathrm{MPa}$ and the rotational speed in the range of $60-100 \%$ of the nominal $\left(n_{\text {nom }}=1150 \mathrm{~min}^{-1}\right)$.

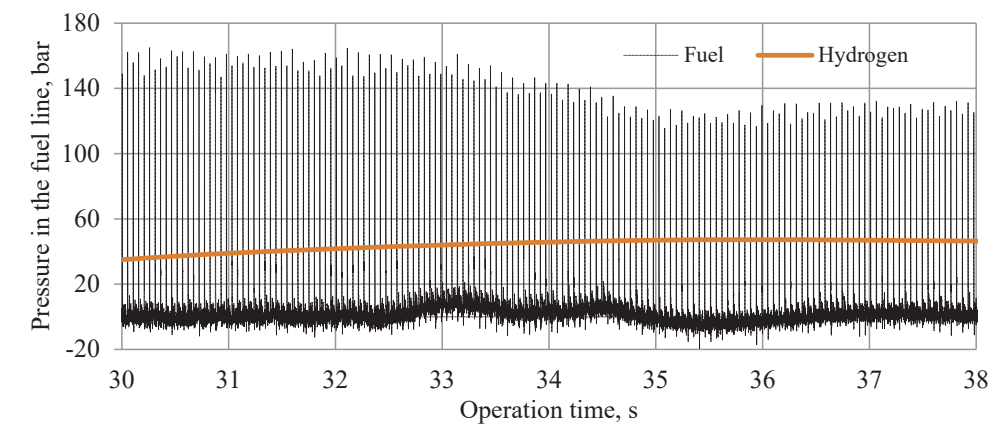

Fig. 6. Experimental diagram of fuel injection with the hydrogen addition

Table 1

Characteristics of the instrumentation of the ДВС-1-МДВ experimental stand

\begin{tabular}{|c|c|c|c|}
\hline $\begin{array}{c}\text { Name of the measuring } \\
\text { instrument, equipment }\end{array}$ & Вгаnd & Measurement limit & $\begin{array}{c}\text { Measurement } \\
\text { еггог }\end{array}$ \\
\hline Tachometer & «ВымПел» & $600 . .8000$ min $^{-1}$ & $\pm 1 \%$ \\
\hline Dynamic pressure sensor & «Dptrand AutoPSI-52000» & $0 . .200 \mathrm{MPa}$ & $\pm 0.5 \%$ \\
\hline Pressure meter & «0ВЕН ПД100-ДИ6,0» & $1.2 \ldots .6 .0 \mathrm{MPa}$ & $\pm 0.5 \%$ \\
\hline Frequency meter & Ч4-34А & $10 \mathrm{~Hz} . .120 \mathrm{MHz}$ & \pm 1 counter unit \\
\hline
\end{tabular}

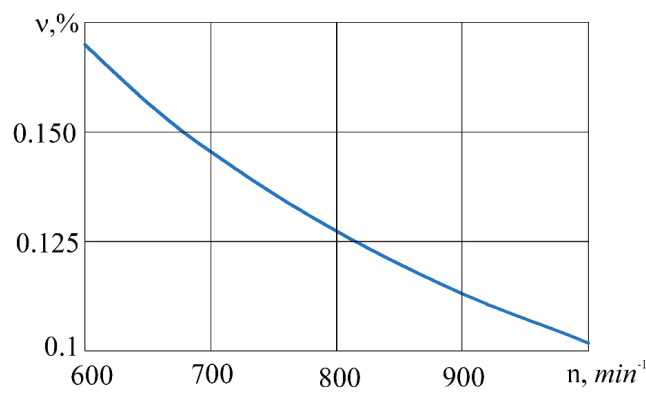

— Fuel — Hydrogen

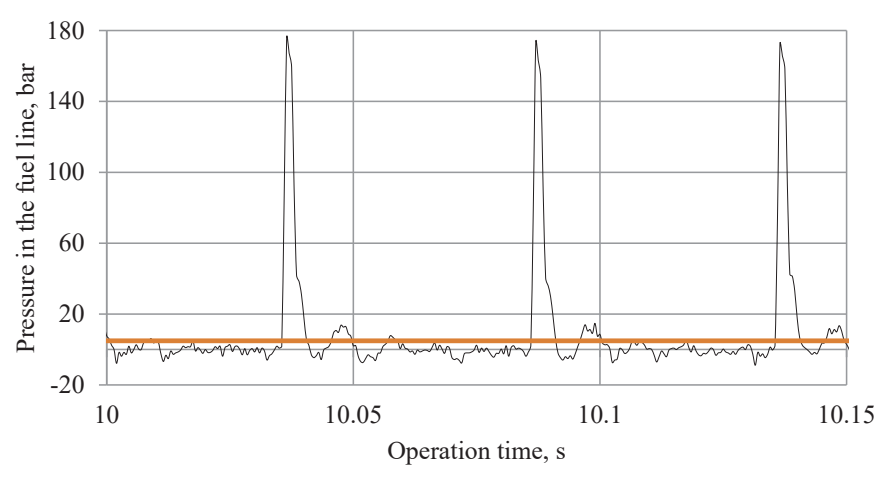

a

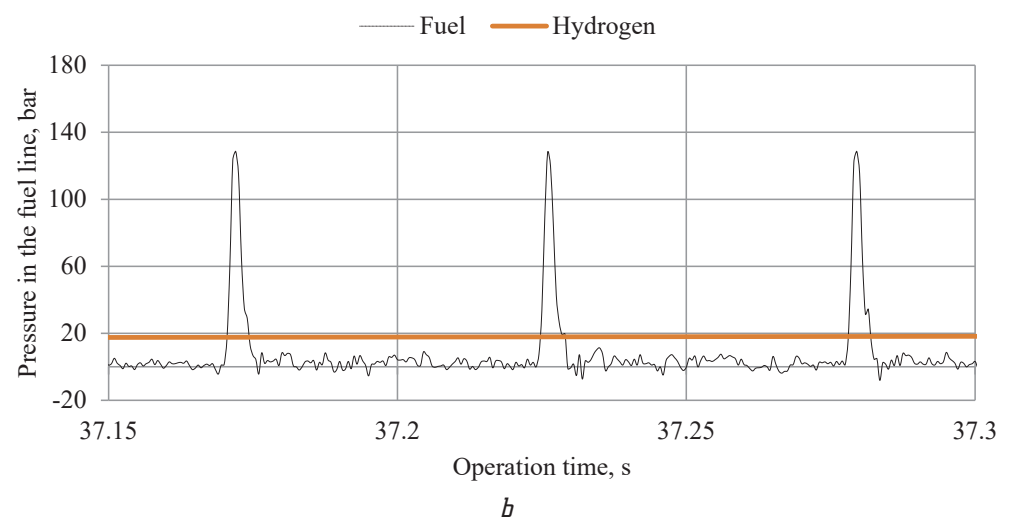

Fig. 5. Fuel injection diagram (a number of injections are highlighted): $a$ - without hydrogen addition; $b$ - with addition

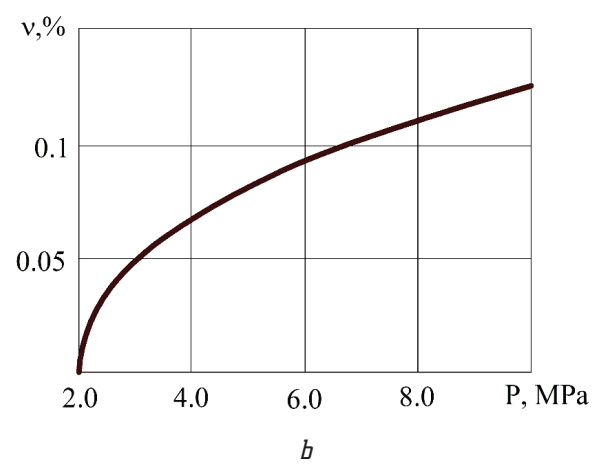

Fig. 7. Dependence of the cyclic supply of hydrogen additives on: $a$ - crankshaft rotational speed (at a hydrogen pressure of $7 \mathrm{MPa}$ ); $b$ - hydrogen supply pressure (at a crankshaft rotation frequency of $1000 \mathrm{~min}^{-1}$ )

Analyzing the obtained results, it is possible to conclude that the appropriate pressure for the supply of hydrogen in the entire range of allowable rotational speeds of a crankshaft of a diesel engine is 5-8 $\mathrm{MPa}$. Such boundaries are primarily due to the optimal concentration of hydrogen and the limits of its solubility [7], as well as issues of its safe storage and operation of hydrogen.

In conclusion, it should be noted that at the moment, the qualitative dependence of the influence of the hydrogen addition on the environmental performance parameters and 
the fuel efficiency of the internal combustion engine is still not fully understood. This predetermines the task of subsequent experimental studies on the real engine of the influence of the proportion of hydrogen additive on the effective fuel consumption, the characteristics of intra-cylinder processes (to produce an indicator diagram of the internal combustion engine) and the concentration of pollutants with exhaust gases.

\section{SWOT analysis of research results}

Strengths. The use of small additives of hydrogen in the high-pressure fuel pipe leads to an increase in engine power by $3 \ldots 7 \%$, depending on the amount of the additive and the engine load. The component of hydrogen combustion in the heat balance is $1 \ldots 3 \%$, the cost of hydrogen in this case does not exceed $2 \%$ of the cost of fuel.

The use of small additions of hydrogen in the amount of $0.1 \%$ of the cyclic dose of fuel leads to a decrease in the specific fuel consumption by $2.3 \ldots 3.7 \%$ depending on the operation mode of the engine.

In comparison with existing methods of adding hydrogen to diesel internal combustion engines, this method helps to preserve the excess air ratio, has minimal hydrogen consumption $(0.1 \%$ compared to $5 . .10 \%$ in the case of supply to the intake duct). Regulation of a hydrogen portion is carried out by adjustments of the fuel equipment and does not require additional equipment.

Weaknesses. Certain difficulties are caused by the organization of fuel supply process in the internal combustion engine in the case of using small additions of hydrogen. So, in the case of hydrogen overpressure there is a threat of gas locks on the high pressure line. This is fraught with a violation of the stable operation of the engine, missed outbreaks, deterioration of environmental performance and engine reliability.

Opportunities. Further development of this method requires the development of a mathematical model of the hydrogen solubility with this method of its addition. The application of this method of hydrogen addition is modeled for the vessel type tanker «SVL LIBERTY» (launched by the SMG «Kherson shipyard», Ukraine) with deadweight of 6970 tons. So with an average transition in 1800 miles, fuel savings of up to $850 \mathrm{c}$. u. for the voyage, taking into account the cost of hydrogen.

Threats. Among the costs for the implementation of this technology, it is necessary to consider equipment with metal hydride hydrogen accumulators, an electrolyzer and a hydrogen supply system. The second difficulty is equipping the vessel with additional safety measures for the use of explosive gases. Among the analogues of this method, it is necessary to single out the use of dual-fuel injectors [7], but in this case the design of the fuel system is much more complicated and its reliability is reduced.

\section{Conclusions}

1. A physical model of wave oscillations in the fuel equipment of a diesel engine has been developed, which substantiates the expediency and possibility of using small hydrogen additives in the fuel on the pressure drop line. A feature of this model is the ability to take into account the time intervals of the injection phase separation, divided into segments, respectively, resulting fluctuations in the pipeline. In further modeling of the hydrogen absorption process, the injection phase sections are taken into account to refine the dissolution model.

2. An experimental stand has been created, including a computer system for collecting, recording and processing measurement data. This allows to research processes in the fuel line of the engine of high pressure with the addition of hydrogen.

3. The dependences of the mass fraction of the hydrogen supply to the main fuel from the supply pressure of the additive and the rotational speed of the engine crankshaft has been obtained. It has been established that in addition to the hydrogen supply pressure, the load and high-speed operation of a diesel engine have the same qualitative effect on the saturation process of diesel fuel with hydrogen. In this case, it is expedient to supply hydrogen pressure in the range of $5-8 \mathrm{MPa}$

It has been determined that the addition of hydrogen in the amount of $v=0.1 \%$, when the needle spring of the injector $R_{n s}=17.6 \mathrm{MPa}$ is serially tightened, causes a decrease in the maximum injection pressure $P_{\text {in }}$ by $2 \ldots 3 \mathrm{MPa}$ due to changes in the physicochemical properties of the fuel.

\section{References}

1. Tymoshevsky B., Tkach M., Shalapko D. Methods to improve the performance of diesel engine using hydrogen addicts // Vodniy transport. 2016. Issue 2. P. 24-28.

2. Szwaja S., Grab-Rogalinski K. Hydrogen combustion in a compression ignition diesel engine // International Journal of Hydrogen Energy. 2009. Vol. 34, Issue 10. P. 4413-4421. doi: https://doi.org/10.1016/j.ijhydene.2009.03.020

3. Shkalikova V. P., Patrahal'cev N. N. Primenenie netradicionnyh topliv v dizelyah: monografiya. 2-e izd., dop. Moscow: RUDN, 1993. $64 \mathrm{p}$

4. Utilization of secondary heat energy of marine low speed engine which uses alternative fuel / Tkach M. R. et. al. // Internal Combustion Engines. 2017. Issue 2. P. 8-13. doi: https://doi.org/ 10.20998/0419-8719.2017.2.02

5. Tymoshevskyy B. G., Tkach M. R., Shalapko D. O. Summary mathematical model of hydrogen addition to line high pressure fuel equipment // Visnyk Khersonskoho natsionalnoho tekhnichnoho universytetu. 2017. Vol. 1, Issue 3. P. 233-237.

6. Patrahal'cev N. N. Apparatura dlya gazodizel'nogo processa // Avtomobil'naya promyshlennost'. 2002. Issue 4. P. 22-23.

7. Matievskiy D. D., Vagner V. A. Osushchestvlenie prisadki vodoroda $\mathrm{k}$ toplivu i ee vliyanie na pokazateli raboty dizelya // Dvigatelestroenie. 1985. Issue 2. P. 53-56.

8. Wu H.-W., Wu Z.-Y. Investigation on combustion characteristics and emissions of diesel/hydrogen mixtures by using energy-share method in a diesel engine // Applied Thermal Engineering. 2012. Vol. 42. P. 154-162. doi: https://doi.org/10.1016/j.applthermaleng.2012.03.004

9. A numerical study on a hydrogen assisted diesel engine / An $\mathrm{H}$. et. al. // International Journal of Hydrogen Energy. 2013. Vol. 38, Issue 6. P. 2919-2928. doi: https://doi.org/10.1016/ j.ijhydene.2012.12.062

10. Effects of $\mathrm{H} 2$ addition on combustion and exhaust emissions in a diesel engine / Yang Z. et. al. // Fuel. 2015. Vol. 139 P. 190-197. doi: https://doi.org/10.1016/j.fuel.2014.08.057

11. An experimental study on combustion, performance and emission analysis of a single cylinder, 4-stroke DI-diesel engine using hydrogen in dual fuel mode of operation / Deb M. et. al. // International Journal of Hydrogen Energy. 2015. Vol. 40, Issue 27. P. 8586-8598. doi: https://doi.org/10.1016/ j.ijhydene.2015.04.125

12. Mobasheri R., Seddiq M., Peng Z. Separate and combined effects of hydrogen and nitrogen additions on diesel engine combustion // International Journal of Hydrogen Energy. 2018. Vol. 43, Issue 3. P. 1875-1893. doi: https://doi.org/10.1016/ j.ijhydene.2017.11.070 
13. Pevnev N. G., Ponamarchuk V. V. Influence of hydrogen additive to fuel, on indicator and effective parametersautomobile ice / Vestnik Sibirskoy gosudarstvennoy avtomobil'no-dorozhnoy akademii. 2017. Issue 4-5. P. 42-47.

14. Pavlov D. A., Piontkovskaya S. A., Smolenskiy V. V. The use of hydrogen addition in internal combustion engines with different methods of forming fuel air mixtures // Izvestiya Samarskogo nauchnogo centra RAN. 2016. Vol. 18, Issue 4. P. 924-930
15. Szwaja S., Grab-Rogalinski K. Hydrogen combustion in a compression ignition diesel engine // International Journal of Hydrogen Energy. 2009. Vol. 34, Issue 10. P. 4413-4421. doi: https://doi.org/10.1016/j.ijhydene.2009.03.020

Shalapko Denis, Lecturer, Department of Shipbuilding and Power Engineering, Kherson Branch of Admiral Makarov National University of Shipbuilding, Ukraine, e-mail: denys.shalapko@nuos.edu.ua, ORCID: https://orcid.org/0000-0002-4311-3908

\section{Polovinka E., Slobodianiuk $\mathbf{N}$.} BUILDING A LOAD CHARACTERISTIC OF THE FUEL INJECTION SYSTEM OF
A SHIP'S MEDIUM-SPEED ENGINE
DIESEL IN DYNAMIC TESTS CONDITIONS

Об'єктом дослідження в роботі є гідродинамічні прощеси в паливній системі високого тиску суднового середньообертового двигуна на змінних режимах. Змінні режими становлять значну частину експлуатаційного часу ряду типів суден (буксири, промислові судна та ін.). А для транспортного флоту вони характерні при маневруванні. В останньому випадку особливе значення має надійність і екологічна безпека для зон санітарного контролю. Дослідження прощесів подачі палива на змінних режимах важливі, так як вони в значній мірі визначають всі експлуатачійні характеристики дизеля і недостатньо вивчені.

У роботі представлений експеримент, в якому ставилося завдання отримання навантажувальної характеристики і дослідження перехідних режимів в паливній апаратурі суднового середньообертового дизеля в умовах динамічних випробувань.

В ході дослідження використовувався розроблений апаратно-програмний комплекс, що забезпечує реалізацію плану експерименту, фіксацію, обробку і осциллографування отриманих даних. Розроблено електромеханічну систему переміщенням рейки паливного насоса високого тиску з програмним комп'ютерним управлінням.

Програмою експерименту передбачено зміну положення рейки у всьому діапазоні, що охоплює експлуатаційну навантажувальну характеристику. Дискретне переміщення включало п'ять фіксованих положень рейки зі ступінчастим переходом між ними.

При випробуваннях паливний насос високого тиску зробив 80 ииклів впорскування протягом 44 с. Час переходу між окремими фіксованими положеннями рейки становив 0,44 с. Період стабілізацї гідродинамічних процесів в системі подачі палива близький до 0,22 с.

У дослідженому діапазоні положень рейки $m_{p}=25-5$ мм (6 та 59 иикли) основні параметри подачі палива мали такі значення: $p_{\phi . к}=474-232$ бар; $p_{\phi . в x}=457-222$ бар; $p_{н}=445-162$ бар.

Проведене дослідження показало можливість отримання навантажувальної характеристики шляхом динамічних випробувань, що істотно скорочує час випробувань і підвищує достовірність даних, виключаючи вплив тимчасового тренда параметрів.

Ключові слова: середньооборотний дизель, паливна апаратура, апаратно-програмні засоби безмоторних динамічних випробувань, навантажувальна характеристика, змінні режими.

\section{Introduction}

Variable modes constitute a significant part of the operational period of transport diesel engines [1]. Because of this, such regimes largely determine all the operational characteristics of such power plants. But also for power plants operating mainly with stable loads, variable modes are of great importance, since their quality characterizes reliability in terms of maneuvering and environmental safety in sanitary control zones.

In these areas, the requirements for the content of the most significant component of harmful substances in the exhaust gases of marine diesel engines - nitrogen oxides - are governed by the norms of the International Maritime Organization (IMO) presented in Fig. 1.

In Ukraine, at present, environmental safety standards for exhaust emissions are regulated by the Euro 5 standard.

To ensure the accepted norms and indicators in the field of diesel construction, research is envisaged in the following main areas [3]:

- improvement of engine design (optimization of the fuel supply process);

- consideration of operational factors (optimization of engine operating conditions);

- use of unconventional fuels. 